\title{
Expression of RET and its ligand complexes, GDNF/GFRalpha-1 and NTN/GFRalpha-2, in medullary thyroid carcinomas
}

\author{
Tony Frisk ${ }^{1}$, Filip Farnebo ${ }^{1}$, Jan Zedenius ${ }^{2}$, Lars Grimelius ${ }^{3}$, Anders Höög ${ }^{4}$, Göran Wallin ${ }^{5}$ and \\ Catharina Larsson ${ }^{1}$ \\ ${ }^{1}$ Department of Molecular Medicine, Endocrine Tumor Unit, Karolinska Hospital, Stockholm, Sweden, ${ }^{2}$ Center for Metabolism and Endocrinology. \\ Department of Surgery, Karolinska Institutet at Huddinge University Hospital, Huddinge, Sweden, ${ }^{3}$ Department of Pathology, Uppsala University \\ Hospital, Uppsala, Sweden, ${ }^{4}$ Department of Pathology, Karolinska Hospital, Stockholm, Sweden and ${ }^{5}$ Department of Surgery, Karolinska Hospital, \\ Stockholm, Sweden \\ (Correspondence should be addressed to T Frisk, Department of Molecular Medicine, Endocrine Tumor Unit, CMM L8:01, Karolinska Hospital, \\ S-17176 Stockholm, Sweden; Email: tony.frisk@cmm.ki.se)
}

\begin{abstract}
Objective: Mutations in the RET proto-oncogene are found in about one third of sporadic medullary thyroid carcinomas (MTCs), mostly affecting codon 918. Glial cell line derived neurotropic factor (GDNF) and its membrane-bound GDNF family receptor alpha (GFRalpha-1), as well as neurturin (NTN) and its membrane-bound receptor GFRalpha-2 form a complex with the RET product, a receptor tyrosine kinase, resulting in downstream signaling to the nucleus.

Design: To elucidate the role of these RET ligands in MTC tumorigenesis, their expression was determined in 15 MTC samples, one papillary thyroid carcinoma (PTC) and three normal thyroid tissue specimens.

Methods: The mRNA expression of RET, GDNF, GFRalpha-1, NTN and GFRalpha-2 was investigated by mRNA in situ hybridization, and confirmed by reverse transcription-PCR analysis.

Results: None of the five genes was expressed in the normal thyroids or in the PTC. All MTCs showed expression of RET, 13 expressed GDNF, 12 expressed GFRalpha-1 and 9 expressed NTN and GFRalpha-2. In 7 of the tumors RET, GDNF and GFRalpha- 1 were expressed at high levels, and in five of these seven tumors NTN and GFRalpha-2 genes were also expressed at high levels. The high level of expression was preferentially seen in tumor cells adjacent to stroma and connective tissue. All MTCs without expression of the RET ligands harbored the RET codon 918 mutation.

Conclusions: The results suggest that this signaling pathway is important for MTC development, and that it may be activated by expression of the RET ligand complexes by the tumor cells themselves.
\end{abstract}

European Journal of Endocrinology 142 643-649

\section{Introduction}

Medullary thyroid carcinoma (MTC) is a rare tumor comprising $5-10 \%$ of all carcinomas in the thyroid gland. The majority of MTC cases occur sporadically, however, approximately $25 \%$ of the patients have a familial form of the disease, such as multiple endocrine neoplasia type 2A and B (MEN 2A and B) and familial MTC (FMTC).

The RET proto-oncogene encodes for a tyrosine kinase receptor. The ligands, glial cell line derived neurotropic factor (GDNF) and neurturin (NTN), and their membrane bound receptors, GFRalpha-1 and GFRalpha-2, form a complex with RET. This results in the dimerization of RET, leading to the activation of its tyrosine kinase function, and allowing it to transduce downstream signaling to the nucleus by phosphoryl-ation of tyrosine residues in signaling proteins (1). In vitro and in vivo studies have shown that GDNF can enhance the survival of various neurons by pre-venting apoptosis $(2,3)$. NTN and GFRalpha-2 are structurally highly homologous to GDNF and GFRalpha-1 respectively $(4,5)$. Recently, two additional ligand complexes have been described for RET. These are artemin and persephin, which activate RET by binding to the membrane bound receptors designated GFRalpha-3 and GFRalpha-4 respectively $(6,7)$. Thus, at least four different ligand systems are involved in RET signaling.

$R E T$ is expressed in both the familial and sporadic forms of MTC. Activating germline RET mutations have been shown to give rise to MEN 2A, MEN 2B, and FMTC and somatic RET mutations have been found in approximately one third of sporadic MTCs $(8,9)$. The 
Table 1 Data on patients, tumor specimens and results from in situ hybridization

\begin{tabular}{|c|c|c|c|c|c|c|c|c|c|c|c|}
\hline \multirow{2}{*}{$\begin{array}{c}\text { Case } \\
\text { no. }\end{array}$} & \multirow{2}{*}{$\begin{array}{l}\text { I.D. } \\
\text { no. }\end{array}$} & \multirow{2}{*}{$\begin{array}{l}\text { Sex }{ }^{a} / \text { Age } \\
\text { at diagnosis }\end{array}$} & \multirow[b]{2}{*}{ Diagnosis } & \multirow[b]{2}{*}{ Sample } & \multirow{2}{*}{$\begin{array}{c}R E T \\
\text { mutation }^{b}\end{array}$} & \multirow[b]{2}{*}{ Survival $^{c}$} & \multicolumn{5}{|c|}{ Expression $^{d}$} \\
\hline & & & & & & & $R E T$ & $G D N F$ & GFRalpha-1 & NTN & GFRalpha-2 \\
\hline 1 & 46 & $\mathrm{M} / 40$ & MTC & Primary & 918 & DfD & ++ & ++ & ++ & ++ & ++ \\
\hline 2 & $\begin{array}{l}378 \\
378 \mathrm{~N}\end{array}$ & $M / 65$ & MTC & Primary & $\begin{array}{l}\text { No } \\
f\end{array}$ & $A w D$ & $\begin{array}{l}++ \\
-\end{array}$ & $\begin{array}{l}++ \\
-\end{array}$ & $\begin{array}{l}++ \\
-\end{array}$ & $\begin{array}{l}++ \\
-\end{array}$ & ++ \\
\hline 3 & 344 & $\mathrm{~F} / 51$ & MTC & Primary & 918 & $A w D$ & + & - & - & - & - \\
\hline & 847 & & & Metastatsis & 918 & & ++ & ++ & ++ & + & + \\
\hline 4 & $\begin{array}{l}1229 \\
1229 \mathrm{~N}\end{array}$ & $\mathrm{~F} / 58$ & MTC & Primary & $\begin{array}{l}918 \\
\text { No }\end{array}$ & AwD & ++ & ++ & ++ & ++ & ++ \\
\hline 5 & 1606 & $\mathrm{~F} / 73$ & MTC & Primary & No & AwoD & ++ & ++ & ++ & ++ & ++ \\
\hline 6 & 1825 & $\mathrm{~F} / 69$ & MTC & Primary & No & AwoD & ++ & ++ & ++ & ++ & ++ \\
\hline 7 & 1848 & $\mathrm{M} / 44$ & MTC & Metastasis & No & AwD & ++ & ++ & ++ & $f$ & $f$ \\
\hline 8 & 40 & $\mathrm{~F} / 76$ & MTC & Primary & No & $A w D$ & + & + & + & + & + \\
\hline 9 & 135 & $\mathrm{~F} / 65$ & MTC & Primary & 918 & DfD & + & - & - & - & - \\
\hline 10 & 595 & $M / 35$ & MTC & Primary & 918 & DfD & + & + & + & - & - \\
\hline 11 & 1072 & $\mathrm{M} / 61$ & MTC & Primary & 918 & AwD & + & + & - & - & - \\
\hline 12 & 1245 & $M / 39$ & MTC & Metastasis & 918 & $A w D$ & + & + & + & + & + \\
\hline 13 & 1500 & $\mathrm{M} / 76$ & MTC & Primary & 918 & AwD & + & + & + & - & - \\
\hline 14 & 1985 & $\mathrm{~F} / 20$ & MTC & Primary & No & AwoD & ++ & + & + & ++ & ++ \\
\hline 15 & 2018 & $F / 34$ & PTC $^{e}$ & Primary & $f$ & AwoD & - & - & - & $f$ & $f$ \\
\hline 16 & $352 \mathrm{~N}$ & $\mathrm{M} / 43$ & $\mathrm{FA}^{e}$ & Normal & $f$ & AwoD & - & - & - & - & - \\
\hline
\end{tabular}

${ }^{a} \mathrm{~F}=$ female, $\mathrm{M}=$ male. ${ }^{b} \mathrm{No}=$ no $R E T$ mutation found. ${ }^{c} \mathrm{DFD}=$ dead from disease; $\mathrm{AwoD}=$ alive without disease; AwD =alive with disease. ${ }^{d}-=$ no cells showing expression; $+=$ minority of cells showing strong expression; $++=$ majority of cells showing strong expression; the assessment was made from the area with maximum of expression. ${ }^{e} \mathrm{PTC}=$ papillary thyroid carcinoma; $\mathrm{FA}=$ follicular adenoma. $f=$ not analyzed.

somatic mutation in the RET gene commonly found in sporadic MTC is identical to the constitutional mutation found in MEN 2B at codon 918 in exon 16, where a methionine is substituted with a threonine. This is a highly conserved substrate-recognition site in the catalytic core of the tyrosine kinase domain, and the presence of this mutation in sporadic MTC has been suggested to correlate with a poor prognosis (10). In addition to the classical Met918Thr mutation, somatic RET mutations in MTC have occasionally been described in other locations including codons $611,634,768$, and 883 (11). In MTCs with RET mutations, ligand independent receptor dimerization and/or substrate specificity shift may occur (11). Thus, in such situations the receptor bound ligand complex is probably not needed for activation of the signaling pathway. However, the ligands have also been shown to increase the transforming activity in cells with the codon 918 mutation, indicating that the RET ligands are important in the oncogenetic pathway $(12,13)$. Hence, in MTCs without detectable RET mutation, a logical probability is that GDNF/GFRalpha-1 or NTN/GFRalpha-2 are somehow involved in the tumor development process. This involvement could theoretically comprise over-expression of the protein, stimulation of different pathways or constitutively activating point mutations.

To further elucidate the role of RET and its ligand complexes in MTC tumorigenesis, the expression of these five genes was analyzed in a panel of such tumors by mRNA in situ hybridization.

\section{Materials and methods}

\section{Patients}

Fifteen thyroid tumor samples from 14 patients operated on for sporadic MTC were snap frozen in liquid nitrogen after removal and stored at $-70{ }^{\circ} \mathrm{C}$ until analysis. The patients ( 7 women and 7 men) had an average age of 55 years at diagnosis (Table 1). Twelve primary tumors and three metastases (nos 3, 7 and 12 in Table 1) were analyzed. From one of the patients two specimens were used, one from the primary MTC and the other from a metastasis (no. 3 in Table 1). Specimens of normal thyroid glands from two patients operated on for MTC and one patient operated on for follicular thyroid adenoma (nos 2, 4 and 16 in Table 1 ), and tumor tissue from one patient operated on for papillary thyroid carcinoma (PTC; no. 15 in Table 1) were obtained and were used as control tissue. The tumors were classified as suggested by the World Health Organisation committee (14). Informed consent was obtained from all patients, and the study was approved by the Ethical Committee of the Karolinska Hospital.

\section{Preparation of probes}

The following synthetic oligonucleotides (Geneset, Paris, France) were used as probes for the in situ hybridization: 5'-GCCCGCACGA AGCTGCCGTT GGCCTGGACC GAGGTCTCGT TGGGC-3' complementary to nt 977-933 
of RET (15); 5'-AACCAGGTTA TCATCTAAAA ACGACAGGTC ATCATCAAAG GCGATGGGT-3' for nt 437389 of GDNF (16); 5'-GGCAGTCAGC GTAGTTTTCC TTTAGACAGC TGCTGACAGA CCTTGA-3' for $\mathrm{nt}$ 1102-1057 of GFRalpha-1 (17); 5'-AGAAGCAGGC CCTCTCGACA CATCCAGATG GACAGCACGG-3' for $\mathrm{nt}$ 86-47 of NTN (4); and 5'-AACTTTACAA TCATACATTT TGCAGCCCTC CTTTTTTGAA-3' for nt 2277-2238 of GFRalpha-2 (5). As a positive control 5'-CTACATGGCA ACTGTGAGGA GGGGAGATTC AGTGTGGTGG GGGAC-3' for nt 1193-1149 of glycerol aldehyde phosphate dehydrogenase $(G A P D H)$ was used. The oligonucleotides were labeled at the $3^{\prime}$ end with $\alpha^{35}$ S-dATP (NEN, Life Science Products, Boston, MA, USA) using terminal deoxynucleotidyl transferase (Amersham Life Science, Tokyo, Japan). The labeled probes were purified using Nensorb-20 columns (Du Pont, Wilmington, DE, USA).

\section{mRNA in situ hybridization}

Cryostat sections $6 \mu \mathrm{m}$ thick were cut and thawmounted on SuperFrostPlus slides (Menzel-Gläser, Braunschweig, Germany). mRNA in situ hybridization was performed as follows. Hybridization solution (50\% formamide, $\quad 4 \times \mathrm{SSC} \quad(1 \times \mathrm{SSC}: \quad 0.15 \mathrm{~mol} / \mathrm{l} \quad \mathrm{NaCl}$, $0.015 \mathrm{~mol} / \mathrm{l}$ sodium citrate), $1 \times$ Denhardt's solution $(0.02 \%$ polyvinyl-pyrrolidone, $0.02 \%$ bovine serum albumin and $0.02 \%$ Ficoll), 1\% N-lauroyl-sarcosine, $0.02 \mathrm{~mol} / \mathrm{l}$ phosphate buffer (pH 7.0), 10\% dextran sulfate, $\quad 500 \mu \mathrm{g} / \mathrm{ml}$ heat-denatured salmon sperm DNA, $200 \mathrm{mmol} / \mathrm{l}$ dithiothreitol, and $37.5 \mu \mathrm{l} / \mathrm{ml}$ of the labeled probes) were mixed and placed in a hybridization oven for $45 \mathrm{~min}$. The solution was spread out on the sections, covered with parafilm, placed in a humidified box and incubated for $16-18 \mathrm{~h}$ at $42{ }^{\circ} \mathrm{C}$. After hybridization, the sections were sequentially rinsed five times $\left(15 \mathrm{~min}\right.$ in $1 \times \mathrm{SSC}$ at $\left.60^{\circ} \mathrm{C}\right)$, left at room temperature for $45 \mathrm{~min}$, and then dehydrated with ethanol in increasing concentrations. After air drying, the sections were exposed to Hyperfilm betamax X-ray film (Amersham, CEA AB, Uppsala, Sweden) for 4-6 days. The sections were then dipped in Kodak NTB-2 emulsion, exposed for 1-4 weeks, developed and finally counterstained with hematoxylin-eosin. The entire procedure was carried out at least twice on consecutive sections. All sections were separately evaluated in both light and dark field microscopy by two independent investigators. Assessment of the in situ hybridization results were as follows: $-=$ no cells showing expression; $+=$ minority of cells showing strong expression; $++=$ majority of cells showing strong expression. The assessment was consistently made from the area showing maximum expression.

\section{Screening for RET mutations}

All MTC specimens except nos 6, 12 and 14 (Table 1) had previously been screened for RET mutations in exons 10, 11 and 16 (18), while MTC specimens nos 6, 12 and 14 were screened for specific mutation in the RET codon 918 in this study. Two rounds of PCR were carried out using three different primers for the RET sequence as described previously (19). Twenty microliters of the second PCR product were then incubated overnight with $2 \mu \mathrm{l} \mathrm{RsaI}$, and the resulting restriction fragments were size-separated in a $6 \%$ polyacrylamide gel. If the RET codon 918 mutation is present, an RsaI restriction site is introduced in the second PCR. Thus the mutation can be resolved as an aberrant restriction pattern on the polyacrylamide gel.

\section{Reverse transcription (RT)-PCR}

In order to verify the specificity of the mRNA in situ hybridization, RT-PCR was performed for all five genes, and the RET product was then further confirmed by EcoRI cleavage. mRNA was isolated from case nos 5 and 8 using Ultraspec-II RNA isolation system (Biotecx Laboratories Inc., Houston, TX, USA). cDNA was synthesized from the isolated mRNA with random primers using a First-Strand cDNA Synthesis Kit (Amersham Pharmacia Biotech, Uppsala, Sweden). The template mixtures were incubated at $37^{\circ} \mathrm{C}$ for $1 \mathrm{~h}$. The primers used in the amplification of RET, GDNF and GFRalpha-1 exons have been described previously $(20,21)$. Primers for NTN and GFRalpha-2 were selected from published sequences and chosen to span exon borders for each gene (f, forward; $r$, reverse): RETf (5'-TCAACATTTG CCCTCAGGAC TG-3'), RETr (5'-TGCAGG CCCC ATACAATTTG-3'), GDNFf (5'TGTCGTGGCT GTCTGCCT-3'), GDNFr (5'-CATCGCAAGA GCCGCTGCAG-3'), GFRalpha-1f (5'-ATGTTCCTGG CGA CCCTGT-3'), GFRalpha-1r (5'-AGTTGGTCTC CTTG CCCGC-3'), NTNf (5'-AGGGCCTGCT TCTCAGCC-3'), NTNr (5'-AGTAGCGGAA CAGCACCGTC-3'), GFRalpha2f (5'-ACGAGACCCT CCGCTCTTTG-3') and GFRalpha-2r (5'-GGGAGGCTTC GTAGAACTCCTC-3').

PCR amplification was performed for each gene in a total volume of $50 \mu \mathrm{l}$ containing $1 \mu \mathrm{l}$ of the synthesized cDNA, $10 \mathrm{mmol} / \mathrm{l}$ Tris- $\mathrm{HCl}(\mathrm{pH} 8.3), 50 \mathrm{mmol} / \mathrm{l}$ $\mathrm{KCl}, \quad 0.75-1.5 \mathrm{mmol} / \mathrm{l} \quad \mathrm{MgCl}_{2}, 200 \mu \mathrm{mol} / \mathrm{l} \quad \mathrm{dNTP}$, $0.01 \%$ gelatine, $1-2 \mathrm{U}$ Amplitaq DNA polymerase and 1-2 $\mathrm{U}$ of each specific primer. The PCR products were subsequently electrophoresed on $1.4 \%$ agarose gels.

Restriction enzyme cleavage of the RET product was performed by incubating $20 \mu \mathrm{l}$ of the RET PCR product with $20 \mu \mathrm{l}$ buffer and $2 \mu \mathrm{l}$ EcoRI restriction enzyme overnight. Twenty microliters of each digestion were electrophoresed on a $1.4 \%$ agarose gel.

\section{Results}

The expression of RET and its ligand complexes GDNF/ GFRalpha-1 and NTN/GFRalpha-2 was studied by mRNA in situ hybridization on frozen tissue sections 

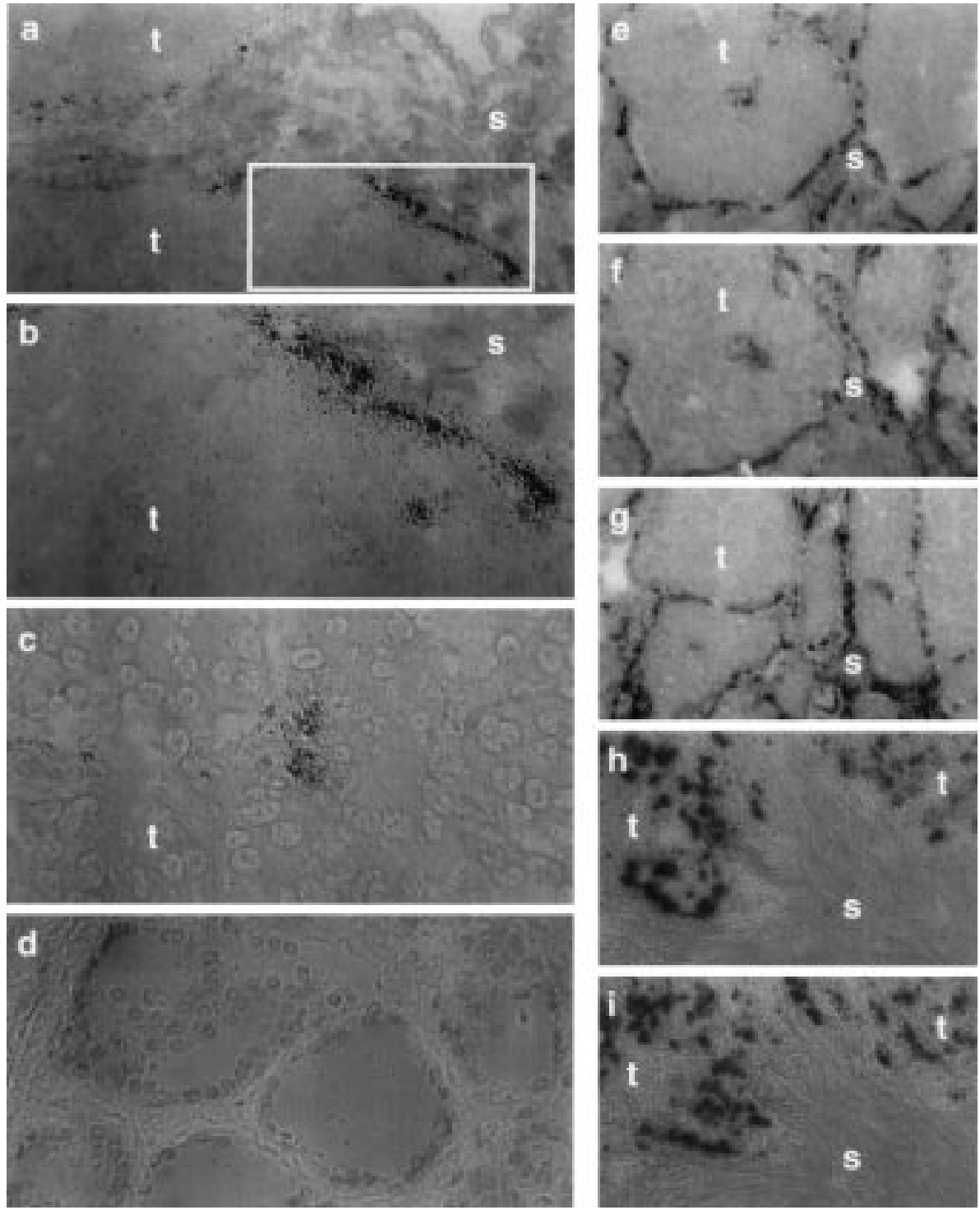

Figure 1 mRNA in situ expression analysis of RET, GDNF, GFRalpha-1, NTN and GFRalpha-2 in medullary thyroid carcinoma. (a and b) Expression of RET in case no. 5 is seen in tumor cells adjacent to the stroma (outlined area in (a) is enlarged in (b)). (c) Expression of $R E T$ in case no. 13. (d) No expression of RET in normal thyroid tissue. (e-i) Two sets of consecutive sections of case no. 4 showing similar expression distribution for (e) RET, (f) GDNF, and (g) GFRalpha-1, and similar expression of (h) NTN and (i) GFRalpha-2. s, stroma; $\mathrm{t}$, tumor. The original magnifications were $(\mathrm{a}) \times 100$, $(\mathrm{b}$ and d) $\times 200$, $(\mathrm{c}, \mathrm{h}, \mathrm{i}) \times 400,(\mathrm{e}-\mathrm{g}) \times 40$.

from 15 MTCs, three normal thyroids and one papillary thyroid carcinoma. The results are illustrated in Fig. 1 and detailed for each case in Table 1 together with the clinical information.

No expression above background level was seen for any of the five genes in the normal thyroid tissues or in the papillary thyroid carcinoma tissue (Table 1). mRNA expression from the positive control gene GAPDH was seen in all normal and tumor specimens (data not shown). RET expression was detected in all MTCs, and for seven of the cases the expression was moderate $(+)$ whilst in eight tumors it was strong $(++)$ (Table 1$)$. In addition, thirteen of the MTCs showed expression of GDNF, twelve of GFRalpha-1, and nine of NTN and GFRalpha-2 (Table 1). In seven of the eight tumors with a strong RET expression a similarly strong expression of GDNF and GFRalpha-1 was evident (Table 1). Moreover, in five of these, strong expression of NTN and GFRalpha-2 was also detected (Table 1; note that one of these MTCs, no. 7, was not analyzed for NTN and GFRalpha-2).

In all the cases where strong expression $(++)$ of RET, GDNF, GFRalpha-1, NTN or GFRalpha-2 was observed, the signals were found in tumor cells typically located adjacent to the stroma, usually peripheral in the tumor 


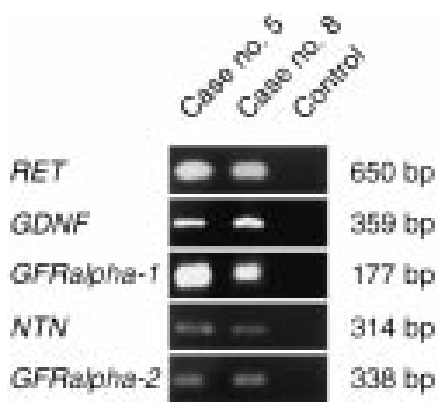

Figure 2 Expression of RET, GDNF, GFRalpha-1, NTN and GFRalpha-2 demonstrated by RT-PCR in two MTCs (case nos 5 and 8), but not in the negative control sample $\left(\mathrm{H}_{2} \mathrm{O}\right)$. The size of each amplified product is indicated in bp on the right.

(Fig. 1). In adddition, the strong expression could also be observed within the tumor in areas where stroma and connective tissue were present. There was no difference in this expression pattern depending on whether the in situ hybridization was performed on specimens from primary tumors or metastases. In the three metastases analyzed, all five genes were found to be expressed, and in two of them, RET, GDNF, and GFRalpha-1 were expressed at high levels $(++)$ (Table $1)$. In addition, in case 3, RET and its ligands showed a stronger expression in the metastasis compared with the primary tumor (Table 1 ).

The fifteen MTC tumor specimens were screened for RET mutations (Table 1). All MTCs without expression of any of the RET ligands harbored a somatic codon 918 mutation, as did three of the seven tumors with strong expression, whilst four did not. No significant difference in the level of RET expression was detected between MTCs with and without the codon 918 mutation. Out of the nine mutation-positive MTCs, three showed a strong and six a moderate expression of RET, and in the six mutation-negative cases the RET expression was strong in five and moderate in one (Table 1).

The expression of mRNA from the five genes was verified by RT-PCR (Fig. 2). The samples tested confirmed the mRNA expression for all five genes. In addition, the positive RET expression was confirmed by restriction enzyme cleavage (data not shown), and as a negative control for the RET gene a series of PTC samples were used (data not shown). Products of the predicted size were seen for all genes in the tumors with positive mRNA in situ hybridization expression, but no product of RET was seen in any of the PTC samples.

\section{Discussion}

The role of RET in the genesis of MEN 2-related tumors is undisputed, as more than $90 \%$ of affected members of MEN 2 and FMTC families harbor germline mutations in this proto-oncogene. In addition, somatic RET mutations occur in sporadic MTCs in $25-60 \%$ of the cases, mainly affecting codon 918. No mutations in the RET gene have previously been described in parathyroid tumors. However, in the second most common MEN 2-related tumor, pheochromocytoma, somatic mutations of RET have been observed in a subset of tumors. Therefore, a logical step should be to examine elements of the RET ligand complexes, to see if activation of this pathway at a different point has occurred, and as such has contributed to the development of tumors. This is especially important for those MEN 2 families which have no documented RET mutation, and also for sporadic MTCs and other MEN 2-related tumors (11). So far, GDNF is the only RET ligand that has been analyzed in this respect, but GDNF mutations could not be demonstrated in such families, nor in sporadic MTCs or pheochromocytomas $(22,23)$. Interestingly, pheochromocytomas express RET, but not GDNF/GFRalpha1 or NTN/GFRalpha-2 (E Edström, unpublished observations), suggesting that for this tumor type, artemin or persephin may be the important RET ligand.

In this study, we have shown that a significant proportion of sporadic MTCs express not only RET, but also GDNF, GFRalpha-1, NTN and GFRalpha-2 mRNA. At least half of the tumors in this series showed a very strong expression of the five genes, and in these cases the expression was preferentially detected in tumor cells adjacent to the stroma.

All MTCs showed at least some expression of RET, in contrast to the papillary thyroid carcinoma and the normal thyroid tissue samples. This might be explained by a lack of C-cells in the analyzed sections, as C-cells normally mostly occur in a centrally located area of the thyroid lobe. In two MTCs no expression of GDNF was demonstrated, three cases lacked GFRalpha-1 expression and for NTN and its ligand GFRalpha-2 no expression was detected in six of the cases. These MTCs harbored a somatic codon 918 mutation, which has been shown to be sufficient to trigger tumor development without the involvement of ligand stimuli (24). However, some tumors with strong expression of all five genes also had the 918 mutation. While signaling through wildtype RET is mediated by ligand complexes, signaling through mutated RET in cells from neuroepithelial origin give rise to phosphorylation and transformation independent of ligand stimulation. Neuroepithelial cells with a typical MEN 2A mutation in RET codon 634 show a higher biological activity than cells with the MEN 2B mutation in codon 918. Nevertheless, when a ligand is added to MEN 2B cells, the activation of RET increases plentyfold and both types of mutated cells are able to induce cell differentiation, in contrast to cells with wildtype RET signaling $(12,13)$. Previous studies have shown that a heterogeneous distribution of the 918 mutation may occur within MTC tumors. Thus, large parts of some MTCs in which a codon 918 mutation has been detected may consist of cells with wildtype RET (25). It would be of interest to determine whether the expressions of GDNF, GFRalpha-1, 
NTN and GFRalpha-2 in the tumors with a 918 mutation in this study occur in tumor areas without a 918 mutation. This could be achieved by microdissection of areas with high expression, followed by PCR amplification and RsaI restriction analysis of the 918 mutation.

The distribution of RET expression and its ligand complexes is striking: in seven of the specimens the expression was found preferentially in tumor cells peripheral in the tumor formations, adjacent to stroma and connective tissue (Fig. 1). These results are in contrast to the findings by immunohistochemical analysis, where RET protein expression was seen in the same MTC subpopulations that also harbored a RET mutation (26). This discrepancy may have several possible explanations, of which the most likely is that the mutated RET leads to increased stability or overexpression of the protein, but not necessarily to increased RNA levels.

A similar distribution pattern has been shown in neuroblastomas, a tumor also derived from the neural crest, where the RET expression was seen only in stroma rich areas (27). This peripheral location of RET expression may be explained by a growth advantage scenario: i.e., the expression can reflect a more proliferative state in these cells, or allow greater invasive properties. The centrally located cells may therefore subsequently undergo a downregulation of this specific expression. The similar expression patterns of GDNF, GFRalpha-1, NTN and GFRalpha-2 could reflect a paracrine or autocrine distribution of these proteins, allowing the peripheral tumor cells maximum growth stimulation. Autocrine and paracrine loops have been suggested to stimulate tyrosine receptor kinases and induce oncogenic activity in different tumors, including stimulation of growth factors (28). However, growth advantage in the cells with high expression of the RET complex may be reflected by other mechanisms. For instance, in vitro studies have shown that GDNF may prevent cell death in dopaminergic neurons, and in vivo can interrupt the apoptotic program in motor neurons $(2,3)$. Furthermore, recently GDNF has been shown to bind to GFRalpha receptors and induce cell survival independent of RET (29).

In summary, most MTCs express RET and its ligand complexes GDNF and GFRalpha-1 as well as NTN and GFRalpha-2 in a specific pattern. The findings suggest that this signaling pathway is an important step in MTC development. In the future, interference somewhere along this pathway could be important in developing new treatment modalities for patients with these tumors.

\section{Acknowledgements}

The authors wish to thank Steven Gray for critical reading of the manuscript. This study was supported by grants from the Swedish Cancer Foundation, the Torsten and Ragnar Söderberg Foundations, the Swedish Medical
Research Council (0102, 2330), the Cancer Society of Stockholm (97-148), and the Magn. Bergvall, the Gustav V Jubilee, and the Fredrik and Ingrid Thuring Foundations.

\section{References}

1 Jing S, Wen D, Yu Y, Holst PL, Luo Y, Fang M et al. GDNF-induced activation of the RET protein tyrosine kinase is mediated by GDNFR- $\alpha$, a novel receptor for GDNF. Cell $1996851113-$ 1124.

2 Yan Q, Matheson C \& Lopez DT. In vivo neurotrophic effects of GDNF on neonatal and adult facial motor neurons. Nature 1995 373 341-344.

3 Oppenheim RW, Houenou LJ, Johnson JE, Lin LF, Li L, Lo AC et al. Developing motor neurons rescued from programmed and axotomy-induced cell death by GDNF. Nature $1995373344-$ 346.

4 Kotzbauer PT, Lampe PA, Heuckeroth RO, Golden JP, Creedon DJ, Johnson EM Jr et al. Neurturin, a relative of glial cell line-derived neurotrophic factor. Nature 1996384 467-470.

5 Buj-Bello A, Adu J, Pinón LGP, Horton A, Thompson J, Rosenthal A et al. Neurturin responsiveness requires a GPI-linked receptor and the RET receptor tyrosine kinase. Nature 1997387 721-724.

6 Baloh RH, Tansey MG, Lampe TJ, Fahrner TJ, Enomoto H, Simburger KS et al. Artemin, a novel member of the GDNF ligand family, supports peripheral and central neurons and signals through the GFRalpha3-RET receptor complex. Neuron 199821 1291-1302.

7 Milbrandt J, de Sauvage FJ, Fahrer TJ, Baloh RH, Leitner ML, Tansey MG et al. Persephin, a novel neurotrophic factor related to GDNF and neurturin. Neuron 199820 245-253.

8 Mulligan LM, Kwok JB, Healey CS, Elsdon MJ, Eng C, Gardner E et al. Germ-line mutations of the RET proto-oncogene in multiple endocrine neoplasia type 2A. Nature 1993363 458-460.

9 Hofstra RM, Landsvater RM, Ceccherini I, Stulp RP, Stelwagen T, Luo Yet al. A mutation in the RET proto-oncogene associated with multiple endocrine neoplasia type $2 \mathrm{~B}$ and sporadic medullary thyroid carcinoma. Nature 1994367 375-376.

10 Zedenius J, Larsson C, Bergholm U, Bovee J, Svensson A, Hallengren B et al. Mutations of codon 918 in the RET protooncogene correlate to poor prognosis in sporadic medullary thyroid carcinomas. Journal of Clinical Endocrinology and Metabolism $1995803088-3090$.

11 Eng C. RET proto-oncogene in the development of human cancer. Journal of Clinical Oncology 199917 380-393.

12 Rizzo C, Califano D, Colucci-D'Amato L, De Vita G, D'Alessio A, Dathan $\mathrm{N}$ et al. Ligand stimulation of a Ret chimeric receptor carrying the activating mutation responsible for the multiple endocrine neoplasia type 2B. Journal of Biological Chemistry 1996 271 29497-29501.

13 Bongarzone I, Vigano E, Alberti L, Borello MG, Pasini B, Greco A et al. Full activation of MEN2B mutant RET by an additional MEN2A mutation or by ligand GDNF stimulation. Oncogene 1998 16 2295-2301.

14 Hedinger CD, Williams ED \& Sobin LH. Histological typing of thyroid tumours. The WHO's international histological classification of tumours, 2nd. rev. edn. Berlin, Heidelberg, New York: Springer, 1988.

15 Takahashi M, Buma Y, Iwamoto T, Inaguma Y, Ikeda H \& Hiai H. Cloning and expression of the RET proto-oncogene encoding a tyrosine kinase with two potential transmembrane domains. Oncogene $19883571-578$.

16 Lin LF, Doherty DH, Lile JD, Bektesh S \& Collins F. GDNF: a glial cell line-derived neurotrophic factor for midbrain dopaminergic neurons. Science $19932601130-1132$.

17 Sanicola M, Hession CA, Worley DS, Carmillo P, Ehrenfels C, Walus L et al. Glial cell line-derived neurotrophic factor-dependent RET activation can be mediated by two different cell-surface 
accessory proteins. Proceedings of the National Academy of Sciences of the USA $1997946238-6243$.

18 Zedenius J, Wallin G, Hamberger B, Nordenskjöld M, Weber G \& Larsson C. Somatic and MEN $2 \mathrm{~A}$ de novo mutations identified in the RET proto-oncogene by screening of sporadic MTCs. Human Molecular Genetics 19943 1259-1262.

19 Zedenius J, Dwight T, Robinson BG, Delbridge L, Backdahl M, Wallin $\mathrm{G}$ et al. A rapid method for DNA extraction from fine-needle aspiration biopsies of thyroid tumors, and subsequent RET mutation analysis. Cancer Detection and Prevention 199822 544-548.

20 Kwok JB, Gardner E, Warner JP, Ponder BA \& Mulligan LM. Structural analysis of the human ret proto-oncogene using exon trapping. Oncogene 19938 2575-2582.

21 Mulligan LM, Timmer T, Ivanchuk SM, Campling BG, Young LC, Rabbitts $\mathrm{PH}$ et al. Investigation of the genes for RET and its ligand complex, GDNF/GFRa-1, in small cell lung carcinoma. Genes, Chromosomes and Cancer 199821 326-332.

22 Marsh DJ, Zheng ZM, Arnold A, Andrew SD, Learoyd D, Frilling A et al. Mutation analysis of glial cell line neurotrophic factor, a ligand for a RET/coreceptor complex, in multiple endocrine neoplasia type 2 and sporadic neuroendocrine tumors. Journal of Clinical Endocrinology and Metabolism 199782 3025-3028.

23 Dahia PL, Toledo SP, Mulligan LM, Maher ER, Grossman AB \& Eng C. Mutation analysis of glial cell line-derived neurotrophic factor (GDNF), a ligand for the RET/GDNF receptor $\alpha$ complex, in sporadic pheochromocytomas. Cancer Research 199757 310313.

24 Santoro M, Carlomagno F, Romano A, Bottaro DP, Dathan NA,
Grieco $\mathrm{M}$ et al. Activation of RET as a dominant transforming gene by germline mutations of MEN 2A and MEN 2B. Science 1995267 381-383.

25 Marsh DJ, Andrew SD, Eng C, Learoyd DL, Capes AG, Pojer R et al. Germline and somatic mutations in an oncogene: RET mutations in inherited medullary thyroid carcinoma. Cancer Research 1996 56 1241-1243.

26 Eng C, Thomas GA, Neuberg DS, Mulligan LM, Healey CS, Houghton $\mathrm{C}$ et al. Mutation of the RET proto-oncogene is correlated with RET immunostaining in subpopulations of cells in sporadic medullary thyroid carcinoma. Journal of Clinical Endocrinology and Metabolism 199883 4310-4313.

27 Nakamura T, Ishizaka Y, Nagoa M, Hara M \& Ishikawa T. Expression of the RET proto-oncogene product in human normal and neoplastic tissue of neural crest origin. Journal of Pathology 1994172 255-260.

28 Porter A \& Vaillancourt R. Tyrosine kinase receptor-activated signal transduction pathways which lead to oncogenesis. Oncogene 199816 1343-1352.

29 Trupp M, Scott R, Whittemore S \& Ibanez C. Ret-dependent and -independent mechanisms of glial cell line-derived neurotrophic factor signaling in neuronal cells. Journal of Biological Chemistry $199927420885-20894$.

Received 4 November 1999

Accepted 11 February 2000 